\title{
A CASE STUDY INTO THE SAFETY COMPLIANCE WITHIN THE ROAD FREIGHT TRANSPORT SECTOR WITH REGARDS TO SECURING CARGO
}

\author{
Ján Ližbetin*, Mária Stopková \\ The Institute of Technology and Business in Ceske Budejovice, Faculty of Technology, Department of Transport and \\ Logistics, Czech Republic \\ *E-mail of corresponding author: lizbetin@mail.vstecb.cz
}

\section{Resume}

This article deals with the issue of safety within the road freight transport sector with regards to the securing of cargo on a vehicle. The first part of the article focuses on the legal framework that regulates this issue in the Czech Republic. The second part is based on a case study and survey conducted among drivers of the road freight transport vehicles into their awareness of what they understand is meant by securing and secure cargo. The case study was carried out in a specific transport company and includes an analysis of the current situation and concrete measures for improving safety while securing timber for transport.

\section{Article info}

Received 17 September 2020

Accepted 30 October 2020

Online 12 March 2021

\section{Keywords:}

road freight transport, lashing and securing cargo, safety, case study

\section{Introduction}

Road freight transport affects all of us, either directly, when we sit behind the wheel, or indirectly, when we pass such vehicles. For some, this means moving products and goods efficiently and conveniently from location to location, for others, it means daily congestion problems. Despite this, there is one thing that binds these groups together, their dependence on cars and trucks.

Road accidents occur on a daily basis, either smaller ones involving only material damage, or serious ones involving the loss of human life. Within this context, it is important to realize that, despite the best efforts of the authorities, the traffic accidents cannot be avoided and we, as traffic participants, must try to prevent them accordingly [1].

The number of accidents as a result of the improper loading or securing of cargo is increasing year by year. For example, in 2009, according to available statistics, an incredible 447 accidents were caused by a technical defect. This represents $5.1 \%$ of the total number of recorded road traffic accidents. The improper loading and securing of cargo represents $39.5 \%$ of this total, with the remainder of the other accidents caused by, among other things, punctured tires, brake failure and apostasy the wheel [2].

\section{Theoretical bases}

Act No. 361/2000 Coll., on Road Traffic and on Amendments to Some Acts, Decree No. 341/2014 Coll., on Approval of Technical Capability and on Technical Conditions of Vehicle Operation on Roads, which repeals Decree No. 283/2009 Coll. are the generally valid regulations relating to the carriage of cargo in the Czech Republic. Act No. 361/2000 Coll. on Road Traffic Section 4 regulates rights and obligations regarding the transport of persons and cargo. The focus of this article is $\S 52$ Carriage of Cargo [3-7].

In the Act on the Conditions of Vehicle Operation on Roads, the amendment of Act No. 168/1999 Coll., on Liability Insurance for Damage Caused by Vehicle Operation and amendments to some related acts (Act on Vehicle Third Party Liability Insurance), as amended by Act No. 307/1999 Coll., the third part (Title II) is the most important. Title II refer to the vehicles type approval in $\$ 16$ and $\S 17$ about application of vehicles type approval. Of particular importance is the following: "The load on the vehicle, even a combination of vehicles, must be evenly distributed and properly secured by suitable technical equipment against movement. If a lashing and clamping set is used to secure the load, it must be in good technical condition and comply with: DIN EN 12195-2 Load restraint assemblies on road 
vehicles - Safety - Part 2: Web lashing made from man-made fibers; DIN EN 12195-3 Load restraint assemblies on road vehicles - Safety - Part 3: Lashing chains; DIN EN 12195-4 Load restraint assemblies on road vehicles - Safety - Part 4: Lashing steel wire ropes; and DIN EN 12195-1 Load restraining on road vehicles - Safety - Part 1: Calculation of securing forces in number and position" [8-13].

DIN EN 12195 applies to design of methods for securing and lashing cargo for transport by road vehicles or parts thereof (trailers, semi-trailers, containers and swap bodies), including their transport on board a ship or by rail and/or combinations thereof. DIN EN 12640 Securing of cargo on road vehicles - Lashing points on commercial vehicles for goods transportation - Minimum requirements and testing specifies the minimum requirements and test methods for lashing points on vehicles and semi-trailers, whereby the maximum permissible weight of the loading structure for general use is 3.5 tons, [14-15]. DIN EN 12642 Securing of cargo on road vehicles - Body structure of commercial vehicles - Minimum requirements specifies the minimum requirements for bodywork (for example sidewalls, end walls, etc.) and provides appropriate test methods to ensure that a vehicle's body structure is able to secure loads, if it is not secured by lashing equipment. This standard applies to vehicle body and semi-trailer structures with a maximum permissible laden weight of more than 3.5 tons [16-19].

Directive 2014/47/EU of the European Parliament and of the Council of 3 April 2014 on the technical roadside inspection of the roadworthiness of commercial vehicles circulating in the Union and repealing Directive 2000/30/ EC imposes an obligation on member states to define an undertaking's responsibilities for maintaining a vehicle in a safe and serviceable condition without prejudice to responsibility of a driver of such a vehicle [20-21].

\section{Materials and methods}

The two main aims of this article are to establish how aware the freight drivers are about lashing and securing cargo and, based on a practical example, to determine what conditions must be met with respect to a specified transport to fulfil all the safety requirements.

\subsection{Driver survey}

During the driver training courses in several companies, a short questionnaire survey was conducted among drivers. The survey focused on establishing their awareness of the issue of securing a cargo. In total, 100 drivers completed the questionnaire. Results of the survey are presented in the following graphs (Figures 1 - 5).

The pie charts above are striking in what they reveal. Firstly, only $6 \%$ of respondents were aware of Directive 2014/47 EU. Similarly, in response to question 5, 6\% of drivers do not consider how much lashing equipment they actually need to sufficiently secure cargoes.
The company owner responded to this issue by stating that most drivers and companies secure cargoes according to the country through which the cargo is to be transported. The reason for this being that the severity of any penalty depends on the place where the controlling authority detects a deficiency. It can therefore be assumed that in the Czech Republic, where it is considered difficult to punish perpetrators based on a vehicle's technical state, not all the companies will comply exactly with the letter of the law.

\subsection{Analysis of securing cargo in a specific company}

The transport company under scrutiny has been operating on the Czech market for four years and can be said to be growing and prospering. The company currently has eight vehicle combinations - six semi-trailers and two trailers - at its disposal. Timber, in the form of logs or full lengths, is the most commonly transported good. The drivers working for this company also completed the aforementioned questionnaire survey. The following pie charts (Figures 6 and 7) show the outcomes for the two most important questions.

Friction lashing is usually used to secure logs or full lengths of wood. The analysis showed that drivers do not pay sufficient attention to the proper loading and securing of their cargoes. Evidence of this can be seen in Figure 8 below. The photograph shows that the cargo is not sufficiently secured and does not comply with the rules that apply to cargoes that exceed a permitted length. If the vehicle were to move or brake suddenly, there is a major risk that the cargo will dislodge itself.

In general, lashing points should be designed and implemented in such a way as to transmit the forces applied to the vehicle's component parts. However, as is evident in Figure 9, there are no lashing points on the vehicle. This is a serious mistake and extremely dangerous, both for the driver and for other road participants.

The lashing equipment used by the company is completely unsuitable. In Figure 10, it is evident that the lashing straps are twisted, which is not permitted under DIN EN 12195-2. This is a major mistake on the part of the driver, who failed to fulfil his obligation to secure the cargo properly. The company responded to this with the following statement: "We will talk about the identified misconduct with the driver and will try to ensure that it does not happen again. We will also remind other drivers of their obligations and will conduct more rigorous checks before the departure of individual vehicles."

Figure 11 shows another mistake made on the part of the driver. The driver has ignored regulation DIN EN 121952, which deals with the component parts of the lashing equipment. Should the driver have been subjected to an inspection by the authorities, the driver would have been obliged to pay a (hefty) fine.

Figures 10 and 11 show the poor quality of the lashing equipment used by the company. Unfortunately, no information could be obtained from the lashing straps 


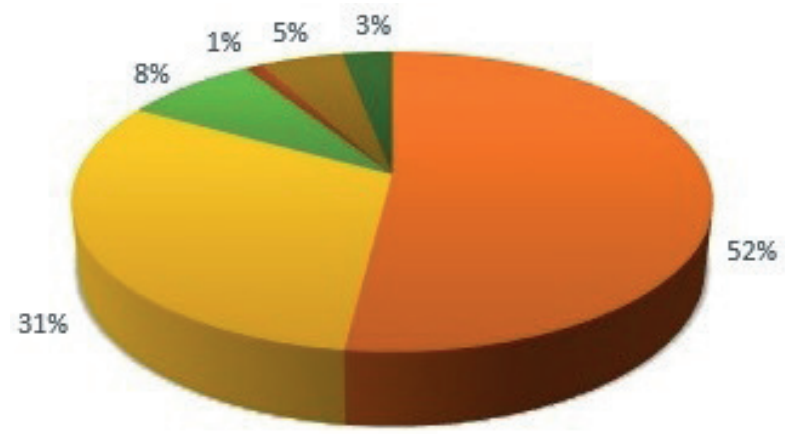

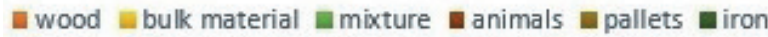

Figure 1 Question 1 results - type of cargo

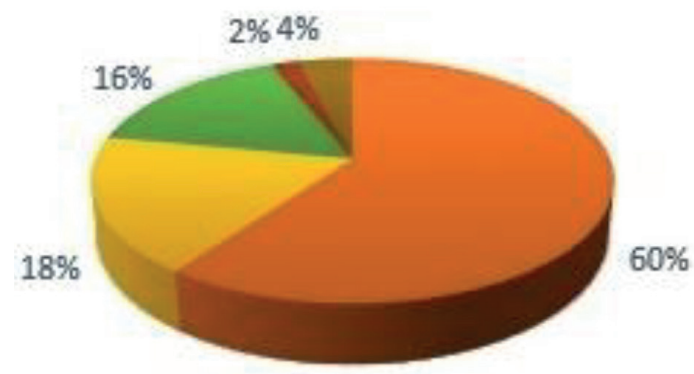

Elashing straps of synthetic fibers achains w ropes wother anone

Figure 2 Question 2 results - types of lashing equipment

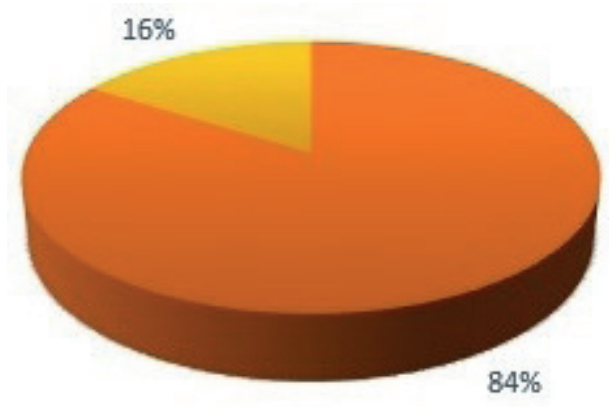

ayes a no

Figure 3 Question 3 results - lashing equipment checks

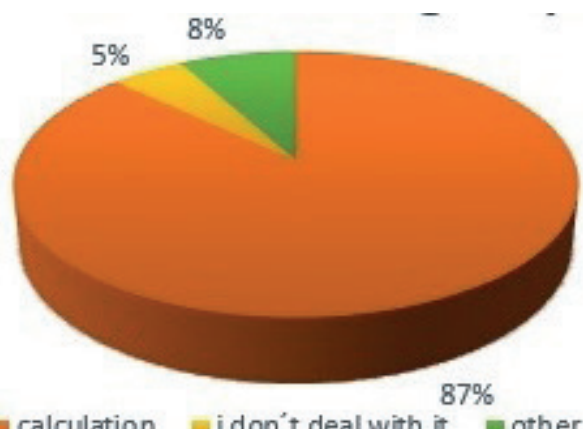

Figure 4 Question 4 results - method for determining the number of lashing straps

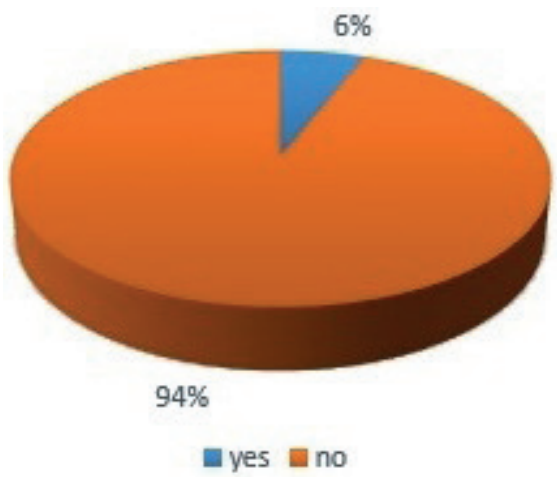

Figure 5 Question 5 results - knowledge about Directive 2014/47 EU

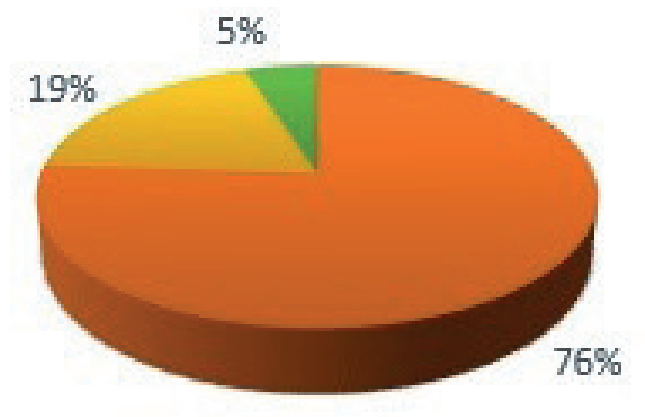

\section{calculation $\mathbf{a}$ I don't deal with it $\mathbf{a t h e r}$}

Figure 6 Method for determining the number of lashing straps

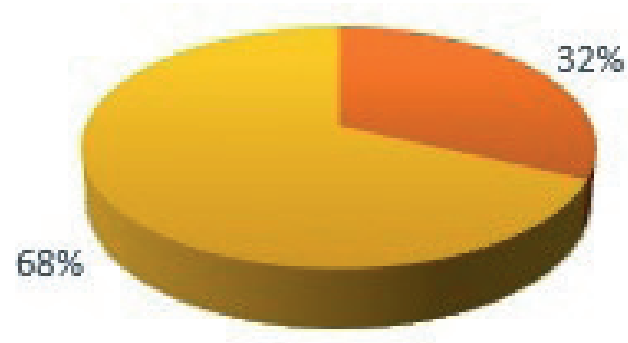

\section{yes $\mathbf{n}$ no}

Figure 7 Lashing equipment check

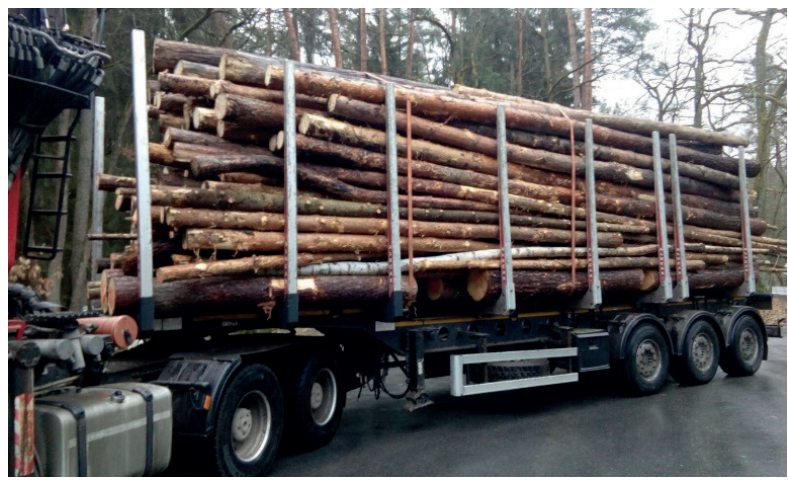

Figure 8 Secured cargo 


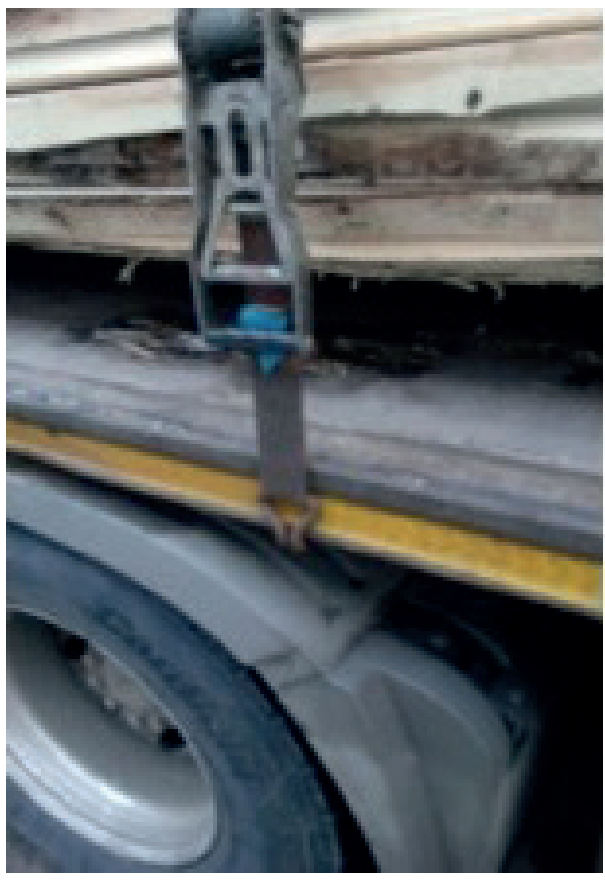

Figure 9 Lashing points

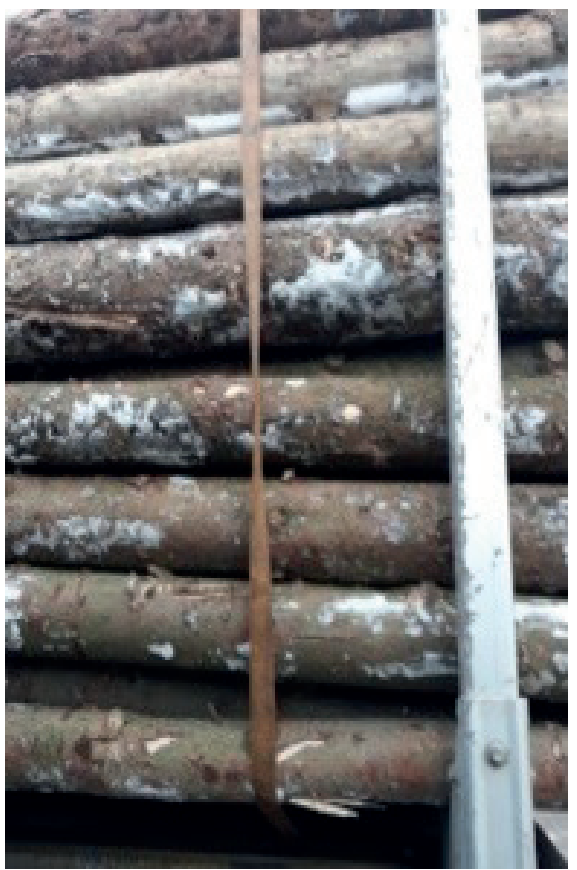

Figure 10 Synthetic lashing straps

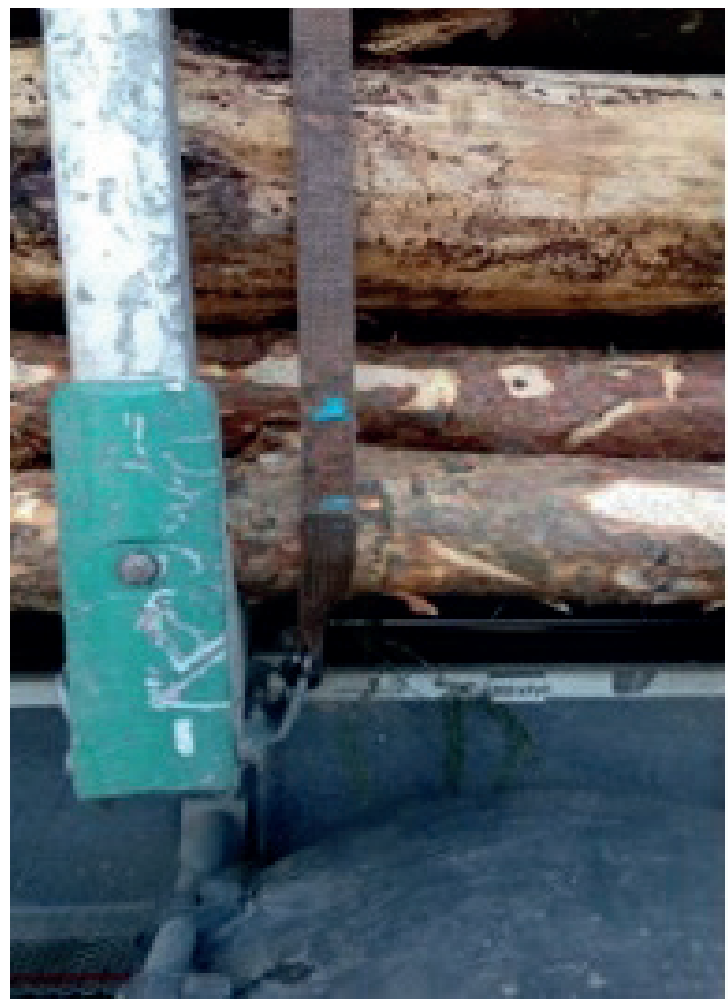

Figure 11 Lashing equipment

to correctly calculate the number of straps required. This raises the question: How do the drivers determine the number of lashing straps required?

\section{Discussion}

The current situation within the company is striking, almost negligent. The company clearly does not care about properly securing loads. This is evidenced by the fact that it has been fined thousands of Czech crowns on many occasions. Unfortunately, this does not appear to be a strong enough deterrent for the company to change its ways.

The company did not want to comment on the missing lashing points on some vehicles. The lashing equipment, which also does not meet the company's standard requirements, will also not be replaced for the time being.

According to the authorities, the general condition of the vehicles means that they should not be used on the 
roads at all. It is their opinion that this, in combination with the unsatisfactory securing of cargo, is endangering the safety of all the road transport participants. Following the adoption of Directive 2014/47 EU, an inspection by the authorities would result in the vehicle being declared roadworthy and the imposition of a fine [22-24].

References [25] include detailed methods for calculating the required number of lashing straps and points, as well as for calculating the total investment for installing the lashing points and purchasing the necessary number of lashing straps.

Calculations by authors suggest that 14 lashing straps are required for the semi-trailers, 5 lashing straps for the trucks and 7 lashing points on the trailers, representing a total investment of CZK 185,264 (cca $6806 €$ ).

\section{Conclusion}

Several measures were put forward to improve the safety of the company's vehicles. Since it owns two types of vehicles, measures were proposed for both.

Firstly, the number of lashing points was calculated. In certain cases, the company was advised to add lashing points to their vehicles. Secondly, the number of lashing straps was calculated according to the DIN EN 12195-1 standard. A fully calculated proposal was subsequently submitted. All this was realized in accordance with applicable standards and in accordance with Directive 2014/47 EU.
As the share of the road freight transport in total traffic increases year by year, it is an imperative to respond appropriately. With the increasing number of vehicles on the roads, the road transport safety is therefore also becoming increasingly important. Due to the increasing range of legislation within this area, authorities may therefore increase their oversight of compliance.

The authors would like to conclude this paper by citing a Supreme Court judgment with regards to a company's appeal against an overloaded vehicle, as determined by the Road Services Center. The judgment was:

"The company's interest in safe roads and traffic is always higher than the fact that the consequences of the uncontrolled shifting of cargo will be to the detriment of the vehicle operator or driver. The load on the vehicle shall be adequately secured, in particular so that both the maximum authorized mass of the vehicle and the maximum permissible mass per axle of the vehicle are not exceeded. If such a condition cannot be achieved and guaranteed for the entire transport, then there is no other option than to not realize the transportation of the cargo at all or to realize the transportation in the form of the authorized special use of a road in compliance with legal conditions."

It is clear from this judgment that any carrier, whether road, rail or otherwise, should take into consideration the safety of traffic first and only then to take economic factors into account. In the case of an accident or prevention, the administrative authority will therefore always take into account the safety aspect.

\section{References}

[1] MCDONALD, N., YUAN, Q., NAUMANN, R. Urban freight and road safety in the era of e-commerce. Traffic Injury Prevention [online]. 2019, 20(7), p. 764-770. ISSN 1538-9588, eISSN 1538-957X. Available from: https://doi.org/10.1080/1 5389588.2019 .1651930

[2] THAMZIL, M., KUSTUNO, D., PURNOMO, SUDJIMAT, D. A., MARDJI. Design engineering freight vehicle load detection perspective competence as an operator, inspectors and auditors for road transport safety. Advanced Science Letters [online]. 2017, 23(2), p. 722-725. ISSN 1936-6612. Available from: https://doi.org/10.1166/asl.2017.7525

[3] Act no. 361/2000 coll. on road traffic. Parliament of the Czech Republic, Czech Republic, 2000.

[4] Decree no. 341/2014 coll. on approval of technical capability and on technical conditions of vehicle operation on roads. Ministry of Transport, Czech Republic, 2014.

[5] HITKA, M., LORINCOVA, S., LIZBETINOVA, L., BARTAKOVA, G.P., MERKOVA, M. Cluster analysis used as the strategic advantage of human resource management in small and medium-sized enterprises in the wood-processing industry. BioResources [online]. 2017, 12(4), p. 7884-7897. ISSN 1930-2126. Available from: https://doi.org/10.15376/ biores.12.4.7884-7897

[6] SABADKA, D., MOLNAR, V., FEDORKO, G. Shortening of life cycle and complexity impact on the automotive industry. TEM Journal-Technology Education Management Informatics [online]. 2019, 8(4), p. 1295-1301. ISSN 2217-8309, eISSN 2217-8333. Available from: https://doi.org/10.18421/TEM84-27

[7] CEMPIREK, V., GASPARIK, J., ZITRICKY, V., BLAHO, P. Control of modular conveyor and automated handling devices interconnection. Advances in Science and Technology-Research Journal [online]. 2018, 12(3), p. 210-215. ISSN 2299-8624. Available from: https://doi.org/10.12913/22998624/94963

[8] Act no. 168/1999 coll. on liability insurance for damage caused by vehicle operation. Parliament of the Czech Republic, Czech Republic, 1999.

[9] DIN EN 12195-2 Load restraint assemblies on road vehicles - safety - part 2: web lashing made from man-made fibres. Czech Office for Standards, Metrology and Testing, Czech Republic.

[10] DIN EN 12195-3 Load restraint assemblies on road vehicles - safety - part 3: lashing chains. Czech Office for Standards, Metrology and Testing, Czech Republic. 
[11] DIN EN 12195-4 Load restraint assemblies on road vehicles - Safety - part 4: lashing steel wire ropes. Czech Office for Standards, Metrology and Testing, Czech Republic.

[12] LI, S., LANG, M., YU, X., ZHANG, M., JIANG, M., TSAI, S., WANG, CH.-K., BIAN, F. A Sustainable transport competitiveness analysis of the China railway express in the context of the belt and road initiative. Sustainability [online]. 2019, 11(10), 2896. eISSN 2071-1050. Available from: https://doi.org/10.3390/su11102896

[13] CERNA, L., ZITRICKY, V., DANIS, J. The methodology of selecting the transport mode for companies on the Slovak transport market. Open Engineering [online]. 2017, 7(1), p. 6-13. eISSN 2391-5439. Available from: https://doi.org/10.1515/eng-2017-0002

[14] DIN EN 12195-1 Load restraining on road vehicles - safety - part 1: calculation of securing forces in number and position. Czech Office for Standards, Metrology and Testing, Czech Republic.

[15] DIN EN 12640 Securing of cargo on road vehicles - lashing points on commercial vehicles for goods transportation minimum requirements and testing. Czech Office for Standards, Metrology and Testing. Czech Republic.

[16] DIN EN 12642 Securing of cargo on road vehicles - body structure of commercial vehicles - minimum requirements. Czech Office for Standards, Metrology and Testing. Czech Republic.

[17] JASKIEWICZ, M., LISIECKI, J., LISIECKI, S., POKROPINSKI, E., WIECKOWSKI, D. Facility for performance testing of power transmission units. Scientific Journals of the Maritime University of Szczecin / Zeszyty Naukowe Akademii Morskiej w Szczecinie. 2015, 42(114), p. 14-25. ISSN 1733-8670.

[18] KAMPF, R., STOPKA, O., BARTUSKA, L. ZEMAN, L. Circulation of vehicles as an important parameter of public transport efficiency. In: International Conference Transport Means 2015: proceedings. 2015. ISSN 1822-296X, p. 143-146.

[19] KOLAROV, I. Training needs on health and safety of drivers at work in road freight transport sector. In: 7th International Conference Efficiency and Responsibility in Education 2010: proceedings. 2010. ISBN:978-80-213-2084-0, p. 174-184.

[20] Directive 2014/47/EU of the European Parliament and of the council of 3 April 2014 on the technical roadside inspection of the roadworthiness of commercial vehicles circulating in the Union and repealing directive 2000/30/EC. European Committee for Standardisation (CEN), European Parliament and of the Council, 2014.

[21] SARKAN, B., STOPKA, O., GNAP, J., CABAN, J. Investigation of exhaust emissions of vehicles with the spark ignition engine within emission control. Procedia Engineering [online]. 2017, 187, p. 775-782. ISSN 1877-7058. Available from: https://doi.org/10.1016/j.proeng.2017.04.437

[22] CABAN, J., VRABEL, J., SARKAN, B., ZARAJCZYK, J., MARCZUK, A. Analysis of the market of electric tractors in agricultural production. MATEC Web of Conferences [online]. 2018, 244, 03005. eISSN 2261-236X. Available from: https://doi.org/10.1051/matecconf/201824403005

[23] SIPUS, D., ABRAMOVIC, B. The possibility of using public transport in rural area. Procedia Engineering [online]. 2017, 192, p. 788-793. ISSN 1877-7058. Available from: https://doi.org/10.1016/j.proeng.2017.06.136

[24] BABIN, M., BUDA, M., MAJERCAK, J. Terminals for transportation of dangerous goods. In: International Conference Transport Means 2012: proceedings. 2012. ISSN 1822-296X, p. 166-170.

[25] CHALUPNA, L. Lashing of cargo in road transport in a selected company / Upevneni nakladu v silnicni doprave ve vybrane firme (in Czech). Diploma thesis. Ceske Budejovice: The Institute of Technology and Business, 2018 